\title{
How Does Allocation of Emotional Stimuli Impact Working Memory Tasks? An Overview
}

\author{
Fabiana Silva Ribeiro, ${ }^{1,2}$ Flávia Heloisa Santos, and Pedro Barbas Albuquerque", \\ 1 Human Cognition Lab, School of Psychology, University of Minho, Campus de Gualtar, 4710-057, Braga, Portugal \\ ${ }^{2}$ Faculty of Education and Psychology (CEDH/HNL), Universidade Católica, Rua Diogo Botelho 1327, 4169-005, Porto, Portugal \\ ${ }^{3}$ School of Psychology, University College Dublin, Stillorgan Rd, Belfield, Dublin 4, Ireland
}

ABSTRACT

In this review, we investigated the influence of happy/pleasurable and sad/unpleasant emotional stimuli on working memory (WM) performance. Twenty-eight out of 356 articles were reviewed. We observed that emotional stimuli were used as mood inductors or as targets comprising the WM task. Results showed that WM modalities were influenced differently when updating, interference resolution, span, and complex tasks were applied. Specifically, we found distinct effects of emotional stimuli for updating tasks, in which (a) verbal modality seems to be impaired regardless of the emotional valence used compared to neutral stimuli, (b) visual updating processes appear to be improved by emotional stimuli as the targets of the task, and (c) emotional words improved interference resolution performance. As for storage, span, and complex WM tasks, sad/unpleasant emotional stimuli seem to decrease both verbal and visuospatial modalities when used as emotional inductors.

\section{INTRODUCTION}

The study of the relationship between emotions and cognitive processes has long been a marginal field in basic psychology. In fact, only in the past three decades did cognitive theories begin to be applied to the scientific analysis of emotions (Tyng, Amin, Saad, \& Malik, 2017). However, the impact that emotions can have on cognitive functions as assessed by various tasks has been demonstrated (Dolan, 2002; Ledoux, 1989). According to previous studies, the area of cognition that may be especially susceptible to the effects of emotion is working memory (WM), a temporary storage system under attentional control that supports the capacity to maintain and manipulate limited information over only a few seconds in the service of complex cognitive tasks such as problem-solving (Baddeley, 1986; Cowan, 1999; Engle \& Oransky, 1999; Jonides \& Smith, 1997).

It is important to highlight that diverse WM tasks exist, which is a consequence of different WM models developed after the model

Corresponding author: Fabiana Silva Ribeiro, Faculty of Education and Psychology (CEDH/HNL), Universidade Católica Potruguesa, Rua Diogo Botelho 1327, 4169005, Porto, Portugal. e-mail: fsribeiro@porto.ucp.pt 
proposed by Baddeley and Hitch (1974). Nevertheless, studies have investigated the extent to which they can be used interchangeably as a measure of WM. For instance, Beatty et al. (2015) explored whether n-back task training could influence delayed matching-to-sample tasks since both are claimed to assess WM. The authors found marginally significant results possibly because the n-back performance requires only constant information updating, while the delayed matching-tosample task recruits other memory functions, such as encoding, maintenance, and retrieval of stimulus representations in sequential order. Moreover, Ivanova, Kuptsova, and Dronkers (2017) explored the relationship between complex span and n-back tasks and found no associations. They suggested that the complex span tasks involve quickly shifting between processes such as storing and rehearsing incoming items while executing a parallel processing task, which is totally different from the $n$-back performance. The authors explain their results supposing that WM and executive functions are not unitary, since previous studies on executive functions revealed that shifting and updating are disconnected processes (Miyake \& Friedman, 2012; Miyake et al., 2000).

Similarly, Jaeggi, Buschkuehl, Perrig, and Meier (2010) revealed that the n-back task is weakly associated with complex WM measures and simple span tasks, especially involving backward sequences. Finally, the results of the above-cited studies suggest that WM measures are not interchangeable, as they might tap into different aspects of the WM process (for more details, see Box 1).

\section{Working Memory and Emotion}

Apart from the WM measurement discussions, a variety of studies have shown that negative or unpleasant emotions can disrupt WM, decreasing its attentional processing (Ribeiro, Albuquerque, \& Santos, 2018). This led some authors to propose that WM might be a cognitive control centre to process emotion and to provide emotional evaluations (Baddeley, 2007; Baddeley, Banse, Huang, \& Page, 2012).

The vast majority of studies examining the link between emotion and WM have focused on anxiogenic and depressive emotional states in clinical samples (Baddeley, 2013; Moran, 2016; Schweizer \& Dalgleish, 2016) rather than healthy samples (Spies, Heese, \& Hunimitzsch, 1996). Researchers have only recently used emotional stimuli as mood inductors in nonclinical samples under two conditions: as a target of the WM task (e.g., Kensinger \& Corkin, 2003) or before WM task performance (e.g., Santos, Soares, \& Albuquerque, 2015; Soares, 2015).

These above-quoted paradigms used positive- (pleasure, e.g., happiness) or negative-valenced stimuli (displeasure, e.g., fear, anger, or sadness, Tyng et al., 2017). Although a variety of unpleasant emotional stimuli are thought to be equally negative in valence (Coan \& Allen, 2003), it is important to point out that studies have already shown that they are clearly distinguished on psychological and experiential grounds (Kreibig, Wilhelm, Roth, \& Gross, 2007). For instance, concerning to the WM performance, a recent meta-analysis carried out by Moran (2016) showed that anxiogenic mood induction before the WM task, which often includes fearful emotional stimuli, could only impair domain-general attentional processes, such as visuospatial complex span and dual-tasks, rather than domain-specific stores.

In contrast, the sad or happy mood induction before WM tasks seems to influence both storage and attentional processing linked to efficient WM functioning. Results of papers using simple span and complex span tasks showed that particularly negative mood induction (sad emotions) may decrease WM performance independently of its modality (Santos et al., 2015; Soares, 2015; Spies et al., 1996). Outcomes seem to demonstrate that participants who are negatively mood-induced are less able to suppress intrusive negative thoughts (Dalgleish \& Yiend, 2006; Taruffi, Pehrs, Skouras, \& Koelsch, 2017). Therefore, ruminant thoughts may influence attention, decreasing WM executive processing and storage resources, leading to worse performance (Baddeley, 2013; Baddeley et al., 2012).

Emotional stimuli used as a target of the WM task seem to affect performance in complex span tasks in different ways, enhancing updating WM task scores (Kensinger \& Corkin, 2003; Pratto \& John, 1991) mainly because results seem to be due to emotion-executive function interactions (Pessoa, 2013). According to this assumption, the association between controlled attention and emotional signals enhances processing of stimuli with affective significance by strengthening its neural representation and increasing the probability that such stimuli are attended to and consciously represented (Vuilleumier \& Huang, 2009). Another study showed that despite the use of emotional stimuli as distractors in a delayed matching-to-sample (DMS) task, performance was impaired for unpleasant items compared to neutral ones, especially when they were highly arousing (Dolcos \& Denkova, 2014).

Finally, some studies observed that verbal stimuli (emotional or not) presented while performing a WM task could disrupt its capacity. This effect is named irrelevant sound, irrelevant speech, or unattended speech effect (Beaman \& Jones, 1997; Jones, Miles, \& Page, 1990; Salamé \& Baddeley, 1989) and occurs because an external sound may interfere with episodic memory activation (Elliott \& Cowan, 2005).

\section{The Purpose of the Current Review}

It is well established that mood states, such as anxious or depressive-related ones, disrupt WM capacity according to previous systematic reviews (Moran, 2016; Rock, Roiser, Riedel, \& Blackwell, 2014). The present review differs from this perspective by focusing strictly on two emotional states, happy/pleasant or sad/unpleasant, generated by emotional stimuli as mood inductors or as targets composing the WM task in nonclinical samples. Moreover, we will disentangle diverse WM tasks by including different functioning processes in verbal and visual modalities to reveal the complexity of the tasks and avoid misleading generalizations of deleterious or beneficial effects produced by emotional stimuli.

Happy/pleasurable emotion and positive emotion will be used interchangeably in the following topics as well as sad/unpleasant and negative. To our knowledge, there is currently no consensus or even review papers summarizing the effects of these specific emotional stimuli and their induction on WM processing and storage. Therefore, the purposes of this review are: (a) to investigate the effects of happy/pleasant 
and sad/unpleasant emotions on WM performance of healthy participants; and (b) to explore whether happy/pleasant and sad/unpleasant emotional stimuli and/or induction affect WM tasks differently.

\section{METHOD}

\section{Eligibility Criteria}

\section{TYPES OF STUDIES}

In this review, we only included quantitative articles with measures supported by adequate statistical methodology. Likewise, studies must have included specifically happy or/and sad emotional stimuli valence versus neutral stimuli and include one of three different emotional stimulation methods (mood induction procedure before the WM task, during WM task performance, or intrinsic emotional stimuli as the target in the WM task). The emotional stimuli could have been of any type as long as they comprised sad and happy stimulation, such as images, words, sentences, songs, autobiographical memory, posts, gift, or video clips.

\section{TYPES OF WORKING MEMORY TASKS}

The WM tasks could have assessed one or both WM modalities (verbal or/and visual) using any kind of WM measurement, such as storage, simple span, complex span, n-back, delayed matching-tosample tasks, among others.

\section{TYPES OF PARTICIPANTS}

We considered studies that included healthy adult participants. Studies examining subgroups, such as women, were included as well.

\section{Exclusion Criteria}

Concerning the samples, studies (or articles) were excluded if they focused on (a) nonhuman samples or (b) paediatric and geriatric samples. Moreover, papers exploring clinical samples in comparison to a control group (healthy adults) were not included. We also excluded (c) studies investigating sensorial modalities other than verbal and visual, (d) review papers, expanded abstracts, books, chapters, and theses; (e) qualitative reports, (f) training-related studies, (g) genetic studies, (h) pharmacological papers, (i) studies without a WM task or not focused on WM processing and performance caused by emotional stimuli, and (j) papers focused on emotion regulation. Finally, (k) emotional stimuli defined as distractors, (l) facial expressions used as emotional stimuli, or (m) studies including negative pictures depicting just anger (human violence, guns), disgust (vomit, garbage), and fear (snakes, spiders, sharks, medical procedures) were also not included in this review.

\section{Identification of Relevant Papers}

Our first search was carried out on 4 July 2018, in the following electronic databases: Web of Science (Thomson Reuters) including SciELO Citation Index (1991-present); PubMed (NCBI) including MEDLINE, PubMed, Central and in-process/ahead-of-print citations (1980-pre- sent), Scopus (1977-present), and PsycINFO (1806-present). The search terms were “'working memory' AND 'emotion' OR 'valence' OR 'arousal"'. The data search was limited to the English language only. On the PsycINFO database, the following limits were selected: original experimental articles, nonclinical samples, English language, human, and adulthood subjects.

\section{RESULTS}

\section{Search Results}

The original search process is displayed in Figure 1 according to the Systematic Reviews and Meta-Analyses (PRISMA) guidelines (Moher, Liberati, Tetzlaff, \& Altman, 2009). The database search yielded 8.991 articles (without duplicates), in which the titles and abstracts were reviewed. Of these, 356 papers were reviewed in full. Applying the inclusion and exclusion criteria, we detected that the sentence "negative emotion" was applied to a number of emotional stimulus categories such as sad/unpleasant, and in papers related to anxiogenic mood, states such as anxiety, anger, fear, and so forth. On the other hand, only happy/pleasant terms were defined as positive emotions. For this reason, a strict criterion was applied to the reviewed paper goals and procedures. This review excluded papers that investigated anxiogenic induction or defined unpleasant stimuli as anxiogenic. After this scrutiny, we selected 28 articles published from 2006 to 2017 that used happy/pleasant as positive valence and sad/unpleasant as negative valence.

Papers included in this review used a broad range of methods, 14 of which examined the effects of mood induction on WM and 14 used emotional stimuli as targets of five different WM tasks. Specifically, seven papers used updating WM tasks, nine papers used WM storage function tasks, one included both tasks (updating and storage), four included delayed matching-to-sample tasks, four papers used complex span tasks, and three papers used interference resolution tasks.

Sample sizes ranged from 10 to 163 participants, and data collection occurred in 13 different countries: UK $(n=1)$, the USA $(n=7)$, South Korea $(n=1)$, Japan $(n=2)$, the Netherlands $(n=1)$, China $(n=2)$, Brazil ( $n=1)$, Iran $(n=1)$, Sweden $(n=1)$, Germany $(n=4)$, Italy $(n=5)$, Australia $(n=1)$, and Singapore $(n=1)$.

It is important to clarify that we did not conduct a meta-analysis because, according to the Cochrane systematic review guidelines (Higgins \& Green, 2011), combining studies that use different types of control conditions may lead to meaningless results. In fact, we observed diverse paradigms measuring WM performance. In other words, we detected a wide array of WM procedures. Consequently, few studies included control conditions that were similar enough to be considered for a meta-analysis.

Since previous studies revealed that n-back, DMS, and simple and complex span tasks were not interchangeable WM measures (Beatty et al., 2015; Blacker, Negoita, Ewen, \& Courtney, 2017; Byrne, Gilbert, Kievit, \& Holmes, 2019; Kane, Conway, Miura, \& Colflesh, 2007; Jaeggi et al., 2010), papers were grouped according to task to avoid biases related to the different WM processes. Box 1 describes each WM task, the measured functions, their prototype, and variations according to the articles found. 


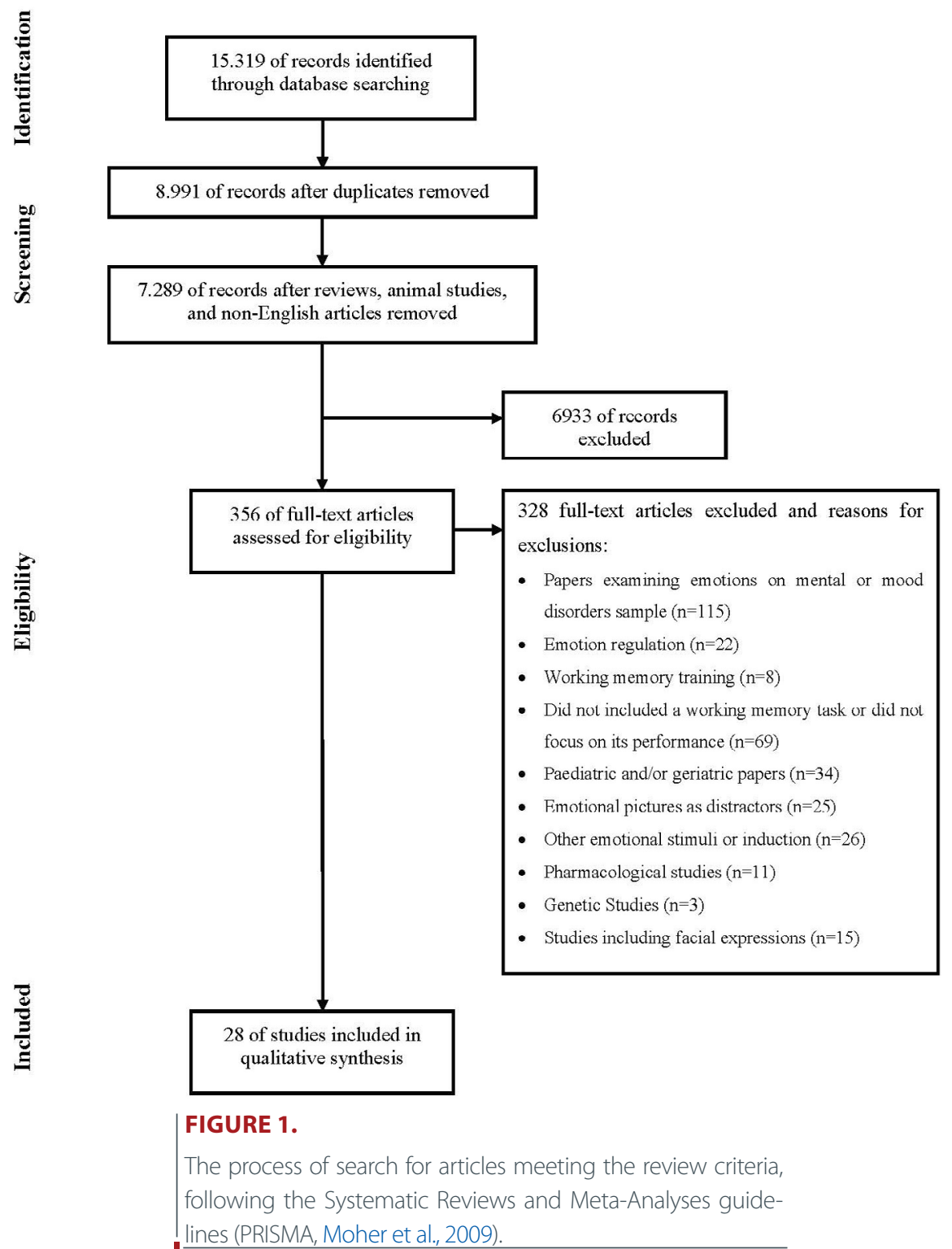

\section{Updating Working Memory Tasks}

As seen in Table 1, seven papers that only assessed updating capacity and one paper including both storage and 2-back tasks were included in this topic. From these eight papers, three included emotional mood induction prior to the n-back task (Chepenik, Cornew, \& Farah, 2007; Choi et al., 2013; Martin \& Kerns, 2011), while the other five included emotional stimuli as the target of the task (Fairfield, Mammarella, Di Domenico, \& Palumbo, 2014; Grimm, Weigand, Kazzer, Jacobs, \& Bajbouj, 2012; Grissmann, Faller, Scharinger, Spüler, \& Gerjets, 2017; Kopf, Dresler, Reicherts, Herrmann, \& Reif, 2013; Lindström \& Bohlin, 2011). Two studies investigating the impact of positive and negative stimuli as targets on n-back tasks found divergent results. Lindström and Bohlin (2011) found that performance in a visual 2-back task increased when positive or negative pictures were used as targets in comparison with neutral pictures, as revealed by higher hit rates, and discriminability, and faster reaction times. In contrast, Grissmann et al. (2017) found that performance in a visuospatial 2-back task decreased when negative pictures were used as targets. Additionally, they showed a decrease in accuracy and slower reaction times in comparison with positive and neutral pictures, but no significant effects of valence of pictures used as targets were observed in the 1-back version of the task.

An important distinction between these studies was how they applied the emotional stimuli in the 2-back task. For example, Lindström and Bohlin (2011) mixed positive, negative, and neutral pictures as targets that would be perceived as distinct stimuli when compared to neutral ones. In turn, Grissmann et al. (2017) created blocks containing only positive, negative, or neutral pictures as targets that might have functioned as mood inductors.

We observed consistent results across studies for verbal modality. They showed that performance in the verbal updating task appears to be decreased by visual induction of emotional words as targets (Choi et al., 2013; Kopf et al., 2013; Fairfield et al., 2014; Martin \& Kerns, 2011). For instance, Choi et al. (2013) and Kopf et al. (2013) revealed poor results for verbal updating tasks. Choi et al. (2013) showed that presenting positive and negative pictures with high arousal as mood 
BOX 1.

Working Memory Tasks, Function Measured, Prototype, and Variations

\begin{tabular}{|c|c|c|c|}
\hline Task & Function & Prototype & Variations \\
\hline $\begin{array}{l}\text { Recency-probes } \\
\text { proactive interference } \\
\text { paradigm }\end{array}$ & $\begin{array}{l}\text { Interference } \\
\text { resolution }\end{array}$ & $\begin{array}{l}\text { Participants go through a sequence of trials in which they } \\
\text { memorize a target set of items and, after a retention interval, } \\
\text { they respond whether the probe matches the items in the } \\
\text { target set. }\end{array}$ & Emotional words or pictures. \\
\hline N-back & Updating & $\begin{array}{l}\text { Participants monitor the identity or location of a series of } \\
\text { verbal or visual stimuli and later indicate whether the current } \\
\text { stimulus is the same as the one presented } n \text { trials earlier. }\end{array}$ & $\begin{array}{l}\text { Emotional pictures or words are } \\
\text { used as the content of the task } \\
\text { itself or pictures that appear in } \\
\text { each trial act as emotion inducers. }\end{array}$ \\
\hline Operation Span & Maintenance & $\begin{array}{l}\text { Each trial consists of the presentation of a sequence of } \\
\text { calculation result judgments followed by an item for } \\
\text { memorization. At the end, the participants recall the items in } \\
\text { their correct serial order. }\end{array}$ & - \\
\hline Corsi Blocks & $\begin{array}{l}\text { Visuospatial } \\
\text { Storage }\end{array}$ & $\begin{array}{l}\text { Participants tap a sequence of blocks in the same order as } \\
\text { the examiner (for storage) or backwards (for processing). } \\
\text { Difficulty progressively increases as the number of items } \\
\text { increases. }\end{array}$ & - \\
\hline Digit Span & Verbal storage & $\begin{array}{l}\text { Participants repeat a sequence of digits verbally in the } \\
\text { same order as the examiner (for storage) or backwards (for } \\
\text { processing). Span lengths range from one to nine items, } \\
\text { increasing progressively. }\end{array}$ & - \\
\hline Running WM & Updating & $\begin{array}{l}\text { Participants see a sequence of items (numbers or letters) and } \\
\text { remember the last items; the number of items to be recalled } \\
\text { varies depending on the research objective. }\end{array}$ & Emotional words. \\
\hline Colour recall & $\begin{array}{l}\text { Visual } \\
\text { storage and } \\
\text { information } \\
\text { precision }\end{array}$ & $\begin{array}{l}\text { Participant see a set of coloured squares and later report the } \\
\text { remembered colour of a probed item by pointing at a colour } \\
\text { wheel. Difficulty increases as the number of items increases. }\end{array}$ & - \\
\hline $\begin{array}{l}\text { Delayed matching-to- } \\
\text { sample }\end{array}$ & $\begin{array}{l}\text { Encoding, } \\
\text { retention, and } \\
\text { retrieval }\end{array}$ & $\begin{array}{l}\text { Stimuli are shown to the participants, followed by a probe } \\
\text { item after a variable delay. They are required to recall whether } \\
\text { the probe item was presented during the encoding phase. }\end{array}$ & Emotional words or pictures. \\
\hline Reading Span & $\begin{array}{l}\text { Maintenance } \\
\text { and retrieval }\end{array}$ & $\begin{array}{l}\text { Participants read sentences while memorizing target words } \\
\text { from the sentences. Difficulty increases as the number of } \\
\text { items gradually increases. }\end{array}$ & Positive and negative sentences. \\
\hline
\end{tabular}

induction was related to reduced verbal 3-back WM task accuracy compared to conditions with neutral pictures. Moreover, Kopf et al. (2013) showed impaired WM performance on a 3-back task that included negative emotional stimuli compared to neutral stimuli since participants produced more errors.

Two other papers assessing the effects of emotion on the running WM task, in which participants should evoke, rather than recognize the stimuli as in the n-back task, support these results. For instance, Martin and Kerns (2011) proposed that positive mood induced by video clips has an impairing effect on a verbal running WM task compared to a neutral condition. They presented 12 to 20 random single-digit numbers to participants and asked them to try to remember the last six digits they heard in forward order. Likewise, Fairfield et al. (2014) used emotional words as targets of a verbal running WM task in which the number of words presented varied from 5 to 8 per trial and participants were instructed to verbally list the last three words of each trial in consecutive order. Data revealed a decrease in accuracy for positive and negative word recollection for longer lists, indicating that task difficulty interacts with valence processing in WM. Moreover, two studies did not detect any effects of emotion on updating performance (Chepenik et al., 2007; Grimm et al., 2012). Specifically, using a mood induction procedure through imagery and music, Chepenik et al. (2007) did not observe any influence of emotions on visual 2-back task performance. Moreover, behavioural task differences were not observed when exploring the neural processing underlying the effects of emotions during updating tasks that used emotional words as targets (Grimm et al., 2012). However, the authors found brain activation variations for emotional stimuli. These studies justified their null findings due to the participants' WM capacity resources, ceiling effects, and the nonaffectivity of the mood induction.

\section{Working Memory Storage and Simple Span Tasks}

As displayed in Table 2, a range of studies investigated WM storage and span capacity in healthy subjects using a variety of induction methods before the WM task (Allen, Schaefer, \& Falcon, 2014; Chepenik et al., 2007; Esmaeili, Karimi, Tabatabaie, Moradi, \& Farahini, 2011; Mayshak, Sharman, \& Zinkiewicz, 2016; Palmiero, Nori, Rogolino, D’Amico, \& Piccardi, 2015, 2016; Palmiero \& Piccard, 2017; Spachtholz, Kuhbandner, \& Pekrun, 2014; Xie \& Zhang, 2016). Only two studies included emotional pictures as the target of the WM task. For example, Mather et al. (2006) applied a short-term source-monitoring task, and Palmiero and Piccard (2017) used the walking Corsi test. In general, effectively induced negative mood, regardless of the method used, seems to decrease WM performance. For example, Allen et al. (2014) 


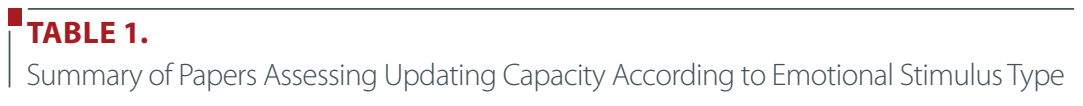

\begin{tabular}{|c|c|c|c|c|c|c|}
\hline $\begin{array}{c}\text { Author } \\
\text { (date) }\end{array}$ & $\begin{array}{c}\text { Emotional } \\
\text { stimuli }\end{array}$ & $\begin{array}{l}\text { Number of } \\
\text { participants }\end{array}$ & Modality & $\begin{array}{c}\text { Valence and/or } \\
\text { arousal }\end{array}$ & $\begin{array}{l}\text { Working } \\
\text { memory } \\
\text { measures }\end{array}$ & Main findings \\
\hline $\begin{array}{l}\text { Grissmann } \\
\text { et al. (2017) }\end{array}$ & Pictures\# & 27 & Visuospatial & $\begin{array}{l}\text { Positive, negative, } \\
\text { and neutral }\end{array}$ & 1 and 2-back & $\begin{array}{l}\text { WM task performance decreased } \\
\text { with negative emotional state in the } \\
\text { 2-back task. }\end{array}$ \\
\hline $\begin{array}{l}\text { Chepenik et } \\
\text { al. (2007) }\end{array}$ & $\begin{array}{l}\text { Imagery and } \\
\text { music }^{*}\end{array}$ & 33 & Visuospatial & $\begin{array}{l}\text { Negative and } \\
\text { neutral }\end{array}$ & 2-back & No findings. \\
\hline $\begin{array}{l}\text { Lindström } \\
\text { and Bohlin } \\
\text { (2011) }\end{array}$ & Pictures\# & 55 & Visual & $\begin{array}{l}\text { Positive, negative, } \\
\text { and neutral }\end{array}$ & 2-back & $\begin{array}{l}\text { WM performance was higher for } \\
\text { positive and negative emotional } \\
\text { targets compared to neutral state. }\end{array}$ \\
\hline $\begin{array}{l}\text { Grimm et } \\
\text { al. (2012) }\end{array}$ & Words\# & 20 & Verbal & $\begin{array}{l}\text { Positive, negative, } \\
\text { and neutral }\end{array}$ & 2-back & No findings. \\
\hline $\begin{array}{l}\text { Choi et al. } \\
\text { (2013) }\end{array}$ & Pictures ${ }^{\star}$ & 20 & Verbal & $\begin{array}{l}\text { Positive, negative, } \\
\text { and neutral }\end{array}$ & 3-back & $\begin{array}{l}\text { WM performance was higher for } \\
\text { neutral emotional states, followed by } \\
\text { positive and negative. }\end{array}$ \\
\hline $\begin{array}{l}\text { Kopf et al. } \\
\text { (2013) }\end{array}$ & Words\# & 32 & Verbal & $\begin{array}{l}\text { Positive, negative, } \\
\text { and neutral }\end{array}$ & 3-back & $\begin{array}{l}\text { WM performance was lower for } \\
\text { the negative stimuli, compared to } \\
\text { positive and neutral. }\end{array}$ \\
\hline $\begin{array}{l}\text { Fairfield et } \\
\text { al. (2014) }\end{array}$ & Words\# & 40 & Verbal & $\begin{array}{l}\text { Positive, negative, } \\
\text { and neutral }\end{array}$ & Running WM & $\begin{array}{l}\text { WM performance with emotional } \\
\text { words decreased as list length } \\
\text { increased. }\end{array}$ \\
\hline $\begin{array}{l}\text { Martin } \\
\text { and Kerns } \\
\text { (2011) }\end{array}$ & Video clip ${ }^{*}$ & $\begin{array}{l}\operatorname{Exp} 1: 180 \\
\operatorname{Exp} 2: 104\end{array}$ & Verbal & $\begin{array}{l}\text { Positive and } \\
\text { neutral }\end{array}$ & Running WM & $\begin{array}{l}\text { WM performance was worse } \\
\text { with the positive emotional state, } \\
\text { compared to neutral. }\end{array}$ \\
\hline
\end{tabular}

Note ${ }^{*}=$ Emotional stimuli as induction; \# = Emotional stimuli as targets of the WM task.

indicated in their experiments that recollecting negative or positive autobiographical emotional memories could impair WM performance across both verbal and visual modalities assessed by the digit recall span and the Corsi span task. Similarly, Spachtholz et al. (2014) showed that negative mood induction through the recollection of negative autobiographical memories and listening to music decreased the storage capacity of items but increased the quality of visuospatial WM representations compared to a neutral mood. In fact, participants more accurately indicatedspecific colours of the squares previously presented as targets to be remembered on a colour wheel with 180 colours.

Mather et al. (2006) used a visual short-term source-monitoring task to investigate whether binding WM performance would decrease as a function of arousal levels (high, medium, or low). Participants had to remember the location of four different pictures from the corresponding subset of positive or negative emotional arousal. The authors concluded that negative high arousal pictures recruited more attention, hence disturbing WM processing capacity compared to neutral and low arousing pictures. Moreover, Palmiero and Piccardi (2017) investigated the effects of neutral, positive, and negative emotional pictures as targets of the walking Corsi test using a between-subjects design. They observed that subjects who performed the test with positive and negative emotional pictures had better scores on the test compared to those exposed to neutral stimuli.

By contrast, positive mood induction seems to improve visuospatial WM processing. For instance, Palmiero et al. $(2015,2016)$, using a Corsi task and the forward and backward walking Corsi test while subjects listened to positive, negative, or neutral songs, revealed that only positive mood was effectively induced comparing pre- and postmood induction measurements, which resulted in increased WM scores when compared to negative and neutral valence music. Both studies used a between-subjects design and they did not apply another WM measure for controlling eventual group differences in WM capacity, which could be crucial to explain the WM results. Another study carried out by Esmaeili et al. (2011) using a between-subjects design investigated the effect of positive and neutral emotional induction through video clips comparing pre- and post-test WM performance, that is, the sum of performances in visuospatial (block recall) and verbal (number-letter) WM tasks. They showed better WM results after the positive induction than after the neutral one. Although the sum of both WM tasks indicated better performance, it is not possible to determine which modality was the most influenced by the positive emotion.

Finally, three papers did not find any influence of emotional induction on WM tasks (Chepenik et al., 2007; Mayshak et al., 2016; Xie \& Zhang, 2016). Although Xie and Zhang (2016) did not present quantitative effects using a valenced picture as induction before a colour and shape WM task, negative induced emotion produced improved resolution compared to the neutral and positive conditions. This means that participants accurately remembered a specific colour when they were asked to find its match on a colour wheel. Spachtholz et al. (2014) showed similar results. Moreover, emotional posts on Facebook (Mayshak et al., 2016) and negative and neutral guided im- 
TABLE 2.

Summary of Papers Evaluating Storage and/or Span Capacity According to Emotional Stimulus Type

\begin{tabular}{|c|c|c|c|c|c|c|}
\hline $\begin{array}{l}\text { Author } \\
\text { (date) }\end{array}$ & $\begin{array}{c}\text { Emotional } \\
\text { stimuli }\end{array}$ & $\begin{array}{l}\text { Number of } \\
\text { participants }\end{array}$ & Modality & $\begin{array}{c}\text { Valence and/or } \\
\text { arousal }\end{array}$ & $\begin{array}{l}\text { Working } \\
\text { memory } \\
\text { measures }\end{array}$ & Main findings \\
\hline $\begin{array}{l}\text { Allen et al. } \\
(2014)\end{array}$ & $\begin{array}{c}\text { Autobiographical } \\
\text { memories }^{*}\end{array}$ & $\begin{array}{l}\text { Exp 1: } 24 \\
\text { Exp 2: } 24\end{array}$ & $\begin{array}{l}\text { Verbal and } \\
\text { visual }\end{array}$ & $\begin{array}{c}\text { Exp.1: } \\
\text { Neutral and } \\
\text { negative } \\
\text { Exp 2: Neutral, } \\
\text { negative, and } \\
\text { positive }\end{array}$ & $\begin{array}{l}\text { Digit recall and } \\
\text { block recall }\end{array}$ & $\begin{array}{c}\text { Spatial and Verbal WM performance } \\
\text { decreased after negative mood } \\
\text { induction. }\end{array}$ \\
\hline $\begin{array}{l}\text { Esmaeili et } \\
\text { al. (2011) }\end{array}$ & Video clips* & 60 & $\begin{array}{l}\text { Verbal and } \\
\text { visuospatial }\end{array}$ & $\begin{array}{l}\text { Positive and } \\
\text { neutral }\end{array}$ & $\begin{array}{l}\text { Number- letter } \\
\text { and block recall }\end{array}$ & $\begin{array}{l}\text { WM results were higher for the } \\
\text { positive induced group than for the } \\
\text { neutral group. }\end{array}$ \\
\hline $\begin{array}{l}\text { Chepenik et } \\
\text { al. (2007) }\end{array}$ & $\begin{array}{c}\text { Imagery and } \\
\text { music }^{*}\end{array}$ & 33 & Verbal & $\begin{array}{c}\text { Negative and } \\
\text { neutral }\end{array}$ & Digit span & No findings. \\
\hline $\begin{array}{l}\text { Mayshak et } \\
\text { al. (2016) }\end{array}$ & Emotional post ${ }^{*}$ & 80 & Verbal & $\begin{array}{l}\text { Positive, negative, } \\
\text { and neutral }\end{array}$ & Digit span & No findings. \\
\hline $\begin{array}{l}\text { Palmiero et } \\
\text { al. (2015) }\end{array}$ & Music* & 111 & Visuospatial & $\begin{array}{l}\text { Positive, negative, } \\
\text { and neutral }\end{array}$ & $\begin{array}{l}\text { Corsi and } \\
\text { walking Corsi } \\
\text { tasks }\end{array}$ & $\begin{array}{l}\text { WM performance was higher for the } \\
\text { positive emotional state compared } \\
\text { to negative and neutral states. }\end{array}$ \\
\hline $\begin{array}{l}\text { Palmiero et } \\
\text { al. (2016) }\end{array}$ & Music ${ }^{\star}$ & 144 & Visuospatial & $\begin{array}{l}\text { Positive, negative, } \\
\text { and neutral }\end{array}$ & $\begin{array}{l}\text { Corsi and } \\
\text { walking Corsi } \\
\text { tasks }\end{array}$ & $\begin{array}{l}\text { WM performance was higher for the } \\
\text { positive emotional state than for the } \\
\text { negative and neutral states. }\end{array}$ \\
\hline $\begin{array}{l}\text { Palmeiro } \\
\text { and Piccard } \\
(2017)\end{array}$ & Images\# & 75 & Visuospatial & $\begin{array}{l}\text { Positive, negative, } \\
\text { and neutral }\end{array}$ & $\begin{array}{l}\text { Walking Corsi } \\
\text { tasks }\end{array}$ & $\begin{array}{l}\text { WM performance was higher } \\
\text { for positive and negative valence } \\
\text { compared to neutral. }\end{array}$ \\
\hline $\begin{array}{l}\text { Mather et } \\
\text { al. (2006) }\end{array}$ & Pictures\# & $\begin{array}{l}\text { Exp 1: } 20 \\
\text { Exp 2A: } 16 \\
\text { Exp 2B: } 10\end{array}$ & Visual & $\begin{array}{l}\text { Positive, negative, } \\
\text { and neutral }\end{array}$ & $\begin{array}{l}\text { Short-term } \\
\text { source- } \\
\text { monitoring task }\end{array}$ & $\begin{array}{l}\text { Memory for picture location } \\
\text { conjunctions decreased as arousal } \\
\text { increased. }\end{array}$ \\
\hline $\begin{array}{l}\text { Spachtholz } \\
\text { et al. (2014) }\end{array}$ & $\begin{array}{l}\text { Autobiographical } \\
\text { memories and } \\
\text { music }^{*}\end{array}$ & 80 & Visual & $\begin{array}{l}\text { Neutral and } \\
\text { negative }\end{array}$ & $\begin{array}{l}\text { Colour recall } \\
\text { task }\end{array}$ & $\begin{array}{c}\text { WM capacity was reduced by } \\
\text { negative valence compared to } \\
\text { neutral. }\end{array}$ \\
\hline $\begin{array}{l}\text { Xie and } \\
\text { Zhang } \\
(2016)\end{array}$ & Pictures ${ }^{\star}$ & $\begin{array}{l}\text { Exp 1: } 18 \\
\text { Exp 2: } 19 \\
\text { Exp 3: } 18\end{array}$ & Visual & $\begin{array}{l}\text { Positive, negative, } \\
\text { and neutral }\end{array}$ & $\begin{array}{c}\text { Colour WM } \\
\text { task, } \\
\text { Shape WM task }\end{array}$ & No findings. \\
\hline
\end{tabular}

agery with valenced excerpts (Chepenik et al., 2007) did not influence performance on the digit span task. These results were interpreted as reflecting inefficiency of the induction method on inducing valence and insufficient arousal to affect WM capacity.

\section{Complex Span Working Memory Tasks}

As shown in Table 3, two papers specifically indicated that visual positive mood induction can increase processing of verbal and visuospatial Operation Span WM tasks (OSPAN - Storbeck \& Maswood, 2015; Yang, Yang, \& Isen, 2013). For example, Yang et al. (2013) observed that positive mood induced by giving participants an unexpected gift (candies) improved performance on a complex WM span task compared to a neutral mood condition. These results are in line with research by Storbeck and Maswood (2015) using video clips as mood inductors. They concluded that positive mood enhanced OSPAN, more precisely the executive control, regardless of modality whereas negative mood did not influence performance.
Nonetheless, Curci, Soleti, Lanciano, Doria, and Rimé (2015) observed that impairment in WM capacity is dependent on the modality (verbal vs. visuospatial) of the original material and the concurrent task. Their results showed that exposure to verbal negative mood induction impaired verbal performance. By contrast, exposure to visual negative mood induction impaired both verbal and visuospatial WM performance. Finally, Osaka, Yaoi, Minamoto, and Osaka (2013) used a reading span task in which participants read sentences that elicited negative, neutral, or positive emotional states while memorizing a target word from each sentence. In other words, participants needed to focus their attention on the target words while ignoring other irrelevant words in the sentences. The data revealed a trend of decreased accuracy for sentences that evoked negative emotional states.

\section{Interference Resolution Tasks}

Levens and Phelps $(2008,2010)$ established that proactive interference WM processing was lower for positive and negative stimuli compared to neutral stimuli. In other words, valenced words were remembered 
TABLE 3.

Summary of Papers Evaluating Working Memory Capacity Through Complex Tasks According to Emotional Stimuli Type

\begin{tabular}{|c|c|c|c|c|c|c|}
\hline $\begin{array}{l}\text { Author } \\
\text { (date) }\end{array}$ & $\begin{array}{l}\text { Emotional } \\
\text { stimuli }\end{array}$ & $\begin{array}{l}\text { Number of } \\
\text { participants }\end{array}$ & Modality & $\begin{array}{l}\text { Valence and/or } \\
\text { arousal }\end{array}$ & $\begin{array}{l}\text { Working } \\
\text { memory } \\
\text { measures }\end{array}$ & Main findings \\
\hline $\begin{array}{l}\text { Osaka et al. } \\
(2013)\end{array}$ & Words ${ }^{*}$ & 26 & Verbal & $\begin{array}{l}\text { Neutral, positive, } \\
\text { and negative }\end{array}$ & Reading Span & $\begin{array}{l}\text { WM scores were lower for } \\
\text { negative valence words. }\end{array}$ \\
\hline $\begin{array}{l}\text { Yang et al. } \\
\text { (2013) }\end{array}$ & Unexpected gift ${ }^{*}$ & 58 & Verbal & $\begin{array}{l}\text { Positive and } \\
\text { neutral }\end{array}$ & OSPAN & $\begin{array}{l}\text { WM (processing and storage) } \\
\text { improved by positive compared to } \\
\text { neutral valence. }\end{array}$ \\
\hline $\begin{array}{l}\text { Storbeck and } \\
\text { Maswood } \\
(2015)\end{array}$ & Video-clips $^{*}$ & $\begin{array}{l}\text { Exp 1: } 120 \\
\operatorname{Exp} 2: 100\end{array}$ & $\begin{array}{l}\text { Verbal and } \\
\text { visual }\end{array}$ & $\begin{array}{l}\text { Negative, positive, } \\
\text { and neutral }\end{array}$ & OSPAN & $\begin{array}{l}\text { Verbal and visuospatial WM } \\
\text { increased with positive mood } \\
\text { induction. }\end{array}$ \\
\hline $\begin{array}{l}\text { Curci et al. } \\
\text { (2015) }\end{array}$ & $\begin{array}{l}\text { Exp 1: two-page } \\
\text { excerpt } \\
\text { Exp 2: video clip* }\end{array}$ & $\begin{array}{l}\operatorname{Exp} 1: 120 \\
\operatorname{Exp} 2: 163\end{array}$ & $\begin{array}{l}\text { Verbal and } \\
\text { visual }\end{array}$ & $\begin{array}{l}\text { Neutral and } \\
\text { negative }\end{array}$ & $\begin{array}{l}\text { OSPAN and an } \\
\text { analog visual } \\
\text { task }\end{array}$ & $\begin{array}{l}\text { Verbal WM performance was } \\
\text { reduced by exposure to negative } \\
\text { visual and verbal induction; } \\
\text { visuospatial WM performance } \\
\text { was reduced by negative visual } \\
\text { induction exposure. }\end{array}$ \\
\hline
\end{tabular}

Note. ${ }^{*}=$ Emotional stimuli as induction. OSPAN $=$ Operation span working memory task.

more often than neutral ones. In another paper, Gotoh (2012) investigated the emotional interference of affective words in continuous auditory processing. He revealed that valenced words (negative and positive) were also recalled better compared to neutral words in trials using words with negative, neutral, and positive affective (see Table 4).

\section{Delayed Matching-to-Sample Tasks}

The effects of emotional stimuli on WM performance were tested in four studies using different delayed matching-to-sample tasks (DMS), as shown in Table 5. Three studies included behavioral tasks and electrophysiological measures (Garcia, Uribe, Tavares, \& Tomaz, 2011; Jin, Li, \& Luo, 2013; Li, Chan, \& Luo, 2010). For instance, Jin et al. (2013) was the only selected paper to use verbal stimuli as the target of a DMS task, in which two target words were presented side by side at the centre of the screen. After a short delay, a word was introduced as a probe stimulus, followed by a blank. The participants were asked to decide whether the probe word was old or new (i.e., whether the probe word was congruent or incongruent with one of the two preceding target words). They were also instructed to try to respond as correctly and quickly as possible. Participants produced faster reaction times and higher accuracy for positive stimuli and, conversely, slower reaction times and lower accuracy for negative stimuli.

Bergmann, Rijpkema, Fernández, and Kessels (2012) presented five consecutive pairs of pictures, each consisting of one neutral picture and one valenced picture, which could be a high-arousal positive, lowarousal positive, high-arousal negative, low-arousal negative, or another neutral picture. Later, participants were asked to indicate whether the current pair matched one of the five pairs presented at the encoding phase. Results showed that high-arousal valenced pictures, whether positive or negative, were less recognized in the test-phase than pairs containing neutral or low-arousal pictures. These results could be a consequence of a higher focus on arousing stimuli, leaving insufficient attentional resources required for binding interitem relationships, thus diminishing WM capacity. Additionally, Garcia et al. (2011) applied a DMS task requiring that participants choose the stimulus from the pair that matched the previously viewed target. In contrast, the nonDMS task required that participants choose the novel stimulus from the pair of stimuli after seeing the target. They showed that participants achieved better results in the DMS than the non-DMS. One explanation given by the authors was based on the unfamiliar response, which may inhibit the instinctively preferred familiar stimuli and decrease attentional resources. Regarding the effects of emotional stimuli, no differences were found between neutral, positive, and negative. On the other hand, authors verified a statistically significant result when comparing neutral and positive stimuli on the non-DMS: improved performance for the neutral stimuli. Additionally, they observed a trend of enhancing effects of the negative emotional content compared to positive content on non-DMS.

Finally, Li et al. (2010) failed to demonstrate the effect of negatively induced emotions on different processing periods in spatial and verbal DMS tasks. They argued that the emotional picture did not sufficiently induce effective negative emotions that could disrupt the processing information since only one different picture was presented before each trial.

\section{DISCUSSION}

Even though the interaction between WM and emotion has an impact on social, academic, professional, and daily life activities, as well as on mental and behavioural disorders, this topic remains understudied. In order to improve our comprehension of how emotion affects WM performance, we implemented a systematic review aiming to (a) scrutinize the body of knowledge about the effects of emotional stimuli on WM performance and (b) observe whether emotional stimuli can enhance or decrease WM 
TABLE 4.

Papers Including Interference Resolution Tasks to Assess Working Memory Capacity According to Emotional Stimuli Type

\begin{tabular}{lcccccc}
\hline $\begin{array}{c}\text { Author } \\
\text { (date) }\end{array}$ & $\begin{array}{c}\text { Emotional } \\
\text { stimuli }\end{array}$ & $\begin{array}{c}\text { Number of } \\
\text { participants }\end{array}$ & Modality & $\begin{array}{c}\text { Valence and/or } \\
\text { arousal }\end{array}$ & $\begin{array}{c}\text { Working } \\
\text { memory } \\
\text { measures }\end{array}$ & Main findings \\
\hline Gotoh (2012) & Words\# & 26 & Verbal & $\begin{array}{c}\text { Positive, negative, } \\
\text { and neutral }\end{array}$ & $\begin{array}{c}\text { Auditory } \\
\text { presentation of } \\
\text { words }\end{array}$ & $\begin{array}{c}\text { WM capacity was higher for } \\
\text { negative and positive words } \\
\text { compared to neutral ones. }\end{array}$ \\
$\begin{array}{l}\text { Levens and } \\
\text { Phelps (2010) }\end{array}$ & Words\# & 27 & Verbal & $\begin{array}{c}\text { Positive, negative, } \\
\text { and neutral }\end{array}$ & $\begin{array}{c}\text { Recency-probes } \\
\text { proactive } \\
\text { interference } \\
\text { task }\end{array}$ & $\begin{array}{c}\text { The degree of proactive } \\
\text { interference decreased with } \\
\text { emotional words compared to } \\
\text { neutral ones. }\end{array}$ \\
$\begin{array}{l}\text { Levens and } \\
\text { Phelps (2008) }\end{array}$ & Words\# & $\begin{array}{c}\text { Exp 1:44 } \\
\text { Exp 2: } 45\end{array}$ & $\begin{array}{c}\text { Verbal and } \\
\text { visual }\end{array}$ & $\begin{array}{c}\text { Positive, negative, } \\
\text { and neutral }\end{array}$ & $\begin{array}{c}\text { Recency-probes } \\
\text { proactive } \\
\text { interference } \\
\text { task }\end{array}$ & $\begin{array}{c}\text { The degree of proactive } \\
\text { interference was smaller with } \\
\text { emotional words than with neutral } \\
\text { ones. }\end{array}$ \\
\hline
\end{tabular}

Note. \# = Emotional stimuli as targets of the WM task.

TABLE 5.

Papers Including Delayed Matching-to-Sample Tasks to Assess Working Memory Capacity

\begin{tabular}{|c|c|c|c|c|c|c|}
\hline $\begin{array}{l}\text { Author } \\
\text { (date) }\end{array}$ & $\begin{array}{c}\text { Emotional } \\
\text { stimuli }\end{array}$ & $\begin{array}{l}\text { Number of } \\
\text { participants }\end{array}$ & Modality & $\begin{array}{c}\text { Valence and/or } \\
\text { arousal }\end{array}$ & $\begin{array}{l}\text { Working } \\
\text { memory } \\
\text { measures }\end{array}$ & Main findings \\
\hline $\begin{array}{l}\text { Bergmann et } \\
\text { al. (2012) }\end{array}$ & Pictures\# & 43 & Visual & $\begin{array}{l}\text { Positive, negative, } \\
\text { and neutral; } \\
\text { Low and high } \\
\text { arousal }\end{array}$ & $\begin{array}{l}\text { Delayed } \\
\text { matching-to- } \\
\text { sample }\end{array}$ & $\begin{array}{l}\text { WM accuracy was lower for pairs } \\
\text { consisting of high arousal images } \\
\text { compared to low arousal images. }\end{array}$ \\
\hline $\begin{array}{l}\text { Garcia et al. } \\
(2011)\end{array}$ & Pictures\# & 54 & Visuospatial & $\begin{array}{c}\text { Negative, positive, } \\
\text { and neutral }\end{array}$ & $\begin{array}{l}\text { Delayed } \\
\text { matching and } \\
\text { non-matching }\end{array}$ & $\begin{array}{c}\text { WM accuracy was lower for } \\
\text { positive pictures compared to } \\
\text { neutral ones on the nonmatching } \\
\text { task. }\end{array}$ \\
\hline $\begin{array}{l}\text { Li et al. } \\
(2010)\end{array}$ & Pictures* & 15 & $\begin{array}{l}\text { Spatial and } \\
\text { verbal }\end{array}$ & $\begin{array}{c}\text { Neutral and } \\
\text { negative }\end{array}$ & $\begin{array}{l}\text { Delayed } \\
\text { matching-to- } \\
\text { sample }\end{array}$ & No findings. \\
\hline $\begin{array}{l}\text { Jin et al. } \\
(2013)\end{array}$ & Words\# & 46 & Verbal & $\begin{array}{c}\text { Negative, positive, } \\
\text { and neutral }\end{array}$ & $\begin{array}{l}\text { Delayed } \\
\text { matching-to- } \\
\text { sample }\end{array}$ & $\begin{array}{l}\text { WM accuracy was higher when } \\
\text { positive stimuli were compared to } \\
\text { negative ones, and WM accuracy } \\
\text { was higher for neutral stimuli } \\
\text { compared to negative ones. }\end{array}$ \\
\hline
\end{tabular}

Note. ${ }^{*}=$ Emotional stimuli as induction; \# = Emotional stimuli as targets of the working memory task.

performance by contrasting updating, storage, complex span, interference resolution, and DMS tasks.

Among the 28 selected quantitative papers, we observed a twofold pattern: papers reporting emotional stimuli used as targets of the task (16 articles) and articles describing studies with emotional stimuli used as inductors before or during the WM task (12 studies). As expected, altogether, these major categories did not show a clear pattern of effects. Firstly, because the WM tasks tap in diverse and unequal WM processes (Beatty et al., 2015; Blacker et al., 2017; Kane et al., 2007; Jaeggi et al., 2010), and secondly, due to the fact that the allocation of emotional stimuli as inductors or targets interacts differently with diverse processes of WM functioning (Baddeley, 2007).

In that sense, scrutinizing the effects of emotional stimuli according to the functions measured by the tasks was an enlightening strategy. Interestingly, we consistently observed that emotional stimulus effects might be modality-specific on updating tasks (seven articles), while storage (nine articles) and complex span tasks (four articles) seem to be mainly affected by opposite valence; for instance, positive valence increases performance and negative valence decreases it. Furthermore, the three studies using interference resolution tasks showed increasing performance regardless of positive or negative verbal stimuli, which were remembered more accurately compared to neutral ones. Finally, results for DMS tasks (four articles) were inconsistent across studies. Specific results for each type of WM task will be discussed in the following sections.

\section{Updating Working Memory Tasks}

There is evidence that visual modality seems to be facilitated by valenced pictures used as the target of the task as well as emotional induction. For instance, applying WM updating tasks (visuospatial 2-back task) with high arousal negative valenced pictures as the target Lindström and Bohlin (2011) revealed higher updating performance compared to neutral pictures. Further, verbal modality seems to be 
impaired by positive high arousal visual induction (Choi et al., 2013; Grissmann et al., 2017; Martin \& Kerns, 2011) or positive and negative emotional words (Fairfield et al., 2014; Kopf et al., 2013) as the targets of the n-back tasks and running WM task.

Positive mood is not related to increases in verbal updating and decreases in visuospatial updating accuracy (D'Esposito et al., 1998; Smith \& Jonides, 1999).

For instance, Martin and Kerns (2011) revealed that positive and negative mood induced by emotional videos equally reduced verbal WM capacity in the running WM task; however, this task has crucial differences when compared to the n-back task (D'Esposito et al., 1998; Smith \& Jonides, 1999). In fact, n-back tasks may be more computationally complex, requiring updating and controlled attention, which could lead to more diffuse brain activity. Therefore, it is possible that differences between the cognitive processes and brain regions involved in the running WM task and n-back tasks can account for the difference in results between studies.

Moreover, another explanation is related to the encoding process of visual and verbal information in the updating tasks. In fact, the visual presentation of items to be stored is likely to encourage dual coding of the stimuli (Paivio, 1991). In other words, when visual stimuli are used as the target in n-back tasks, they seem to be efficiently processed since people tend to spontaneously name visual stimuli by creating a considerable distinction between the images when compared to words that do not spontaneously generate visual images (Klingner, Tversky, \& Hanrahan, 2010). This is plausible since none of the papers using a visual n-back task used an articulatory suppression control procedure.

Finally, we would like to emphasize that the updating task was observed in eight out of 28 papers. Overall, authors focused on an executive process related to WM, which seems to be the current trend in the literature, especially after the proposal of a neural model for WM (D’Esposito, 2007; D’Esposito \& Postle, 2015). According to this view, the quality rather than the quantity of WM representations determines performance (Ma, Husain, \& Bays, 2014). Therefore, authors investigating WM must consider the differences in WM tasks because they can influence their outcomes and the explanations (Redick \& Lindsey, 2013).

\section{Working Memory Storage, Simple Span, and Complex Span Tasks}

Studies investigating WM processing and storage after mood induction found congruent results when negative emotional stimuli were used. More specifically, these papers revealed that negatively induced mood may have a deleterious effect on visuospatial WM. Indeed, the majority of the reviewed papers (Allen et al., 2014; Curci et al., 2015, Mather et al., 2006; Osaka et al., 2013; Spachtholz et al., 2014) provided evidence for such an effect, regardless of the WM task used (colour recall, source-monitoring task, digit recall, block recall, OSPAN, and reading span).

A significant impact on WM functioning also seems to be dependent on the type of negative mood induction: the greater the mood induction effect, the higher the mood arousal (Nguyen \& Grahn,
2017). Thus, more irrelevant self-referent thoughts could be generated and distract participants from the WM task by loading attentional resources (Seibert \& Ellis, 1991; Taruffi et al., 2017) and influencing both storage and active maintenance (Meiran, Chorev, \& Sapir, 2000).

By contrast, positive mood induction seems to improve visuospatial WM performance for storage, span tasks, and complex span tasks (Esmaeili et al., 2011; Palmiero et al., 2015, 2016; Storbeck \& Maswood, 2015; Yang et al., 2013). By observing outcomes from Palmiero et al. (2015, 2016), which used irrelevant sounds as emotional stimuli (background sounds that were not part of the WM task), one can argue that their results, when contrasted with the classical literature, are linked to the irrelevant sound effect (Beaman \& Jones, 1997; Jones et al., 1990; Salamé \& Baddeley, 1989). However, a low arousal condition could have beneficial effects on WM performance compared to silence, since environmental sounds, such as laboratory equipment and furniture, may lead to high arousal effects in a silence condition (Broadbent, 1978).

An explanation regarding positive mood induction effects could be related to the attentional process, which depends on motivational intensity (Gable \& Harmon-Jones, 2008). In other words, the broadenand-build theory (Fredrickson, 2001) states that positive emotional stimuli, as opposed to negative stimuli, promote a broadening of attention capacity, increasing the repertoire of thought and engaging motivation, which may improve performance on attentional processes. Finally, we could not offer conclusions regarding the usage of emotional pictures as targets on a span task since we found that only one article investigated the effects of positive, negative, and neutral pictures as targets in a span WM task (Palmiero \& Piccard, 2017). Their results showed an enhancing effect for positive and negative valenced tasks compared to neutral. According to the authors, this enhancing effect could be due to the distinctiveness of the valenced photos compared to the neutral ones (Ochsner, 2000). However, more studies should be carried out to discuss these results.

\section{Interference Resoultion Tasks}

Regarding the interference resolution tasks, all the three reviewed studies (Gotoh, 2012; Levens \& Phelps, 2008, 2010) presented congruent results regarding the capacity to remember verbal emotional stimuli (positive and negative valence) compared to neutral stimuli. This paradigm mainly manipulates familiarity and source recognition. For this reason, these results indicated that positive and negative verbal items were distinctive when compared to neutral items, mainly because emotional stimuli have probably diminished familiarity signal strength and enhanced emotional source memory, permitting interference resolution for emotional stimuli in WM (Kensinger \& Corkin, 2003).

\section{Delayed Matching-to-Sample Tasks}

Studies using DMS tasks with visuospatial modality produced widely varied effects, which may be associated with procedural differences. For example, Bergmann et al. (2012) used low and high arousal pictures with a much longer delay period compared to other studies and found that visual WM performance was compromised for negative 
pictures with both low and high arousal. The negative stimuli probably led to an increase in attention, thus generating a cost for the binding process.

On the other hand, Li et al. (2010) used a brief mood induction with an emotional picture lasting $1 \mathrm{~s}$, showing no effects of mood induction on the DMS. Finally, Garcia et al. (2011), who used two tasks, the DMS and the non-matching task, showed that negative emotional stimuli were better remembered than positive ones in the non-matching task, where more attention is needed.

\section{CONCLUSION}

In conclusion, we observed that the consequences of emotions on WM performance could be related to: (a) the moment that the emotional stimuli are applied, as a target or as induction previous to the task, and (b) how WM processing and storage is measured. More specifically, negative emotional pictures and negative video clips as mood induction, as well as negative words as the target of verbal updating tasks, may decrease performance. Moreover, the reviewed papers showed that inducing negative mood before storage, span, and complex span tasks can reduce verbal and visuospatial WM capacity. The opposite pattern is observed for positive mood induction, which seems to increase the same type of WM tasks. Concerning interference resolution tasks, emotional words (either positive or negative) were better remembered than neutral ones. Nevertheless, mixed results were found among DMS tasks due to a wide variety of procedures used across papers. Finally, researchers must consider the WM processes involved in the tasks and the function of the underlying emotional stimuli, which could be crucial to explain results and for future replication (Ribeiro et al., 2018).

\section{ACKNOWLEDGEMENTS}

This work was supported by the Brazilian National Council for Scientific and Technological Development - CNPq under Grant 229520/2013-8. Furthermore, this study was partially conducted at the Psychology Research Centre (PSI/01662), School of Psychology, University of Minho, and supported by the Portuguese Foundation for Science and Technology and the Portuguese Ministry of Science, Technology and Higher Education through the State Budget (UID/ PSI/01662/2019).

\section{REFERENCES}

Allen, R. J., Schaefer, A., \& Falcon, T. (2014). Recollecting positive and negative autobiographical memories disrupts working memory. Acta Psychologica, 151, 237-243. doi: 10.1016/j.actpsy.2014.07.003 سلس سلس

Baddeley, A. D. (1986). Working memory. Oxford: Oxford University Press.

Baddeley, A. (2007). Working memory and emotion II. In A. Baddeley (Ed.), Working memory, thought, and action (pp. 277-299). New York: Oxford University Press.

Baddeley, A. (2013). Working memory and emotion: Ruminations on a theory of depression. Review of General Psychology, 17, 20-27. doi:10.1037/a0030029 السلسلس

Baddeley, A. D., Allen, R. J., \& Hitch, G. J. (2011). Binding in visual working memory: The role of the episodic buffer. Neuropsychologia, 49, 1393-1400. doi: 10.1016/j.neuropsychologia.2010.12.042 المسلس

Baddeley, A., Banse, R., Huang, Y.-M., \& Page, M. (2012). Working memory and emotion: Detecting the hedonic detector. Journal of Cognitive Psychology, 24, 6-16. doi: 10.1080/20445911.2011.613820

Baddeley, A. D., \& Hitch, G. J. (1974). Working memory. In G. H. Bower (Ed.), The psychology of learning and motivation (pp. 47-89). New York, NY: Academic Press.

Beaman, C. P., \& Jones, D. M. (1997). Role of serial order in the irrelevant speech effect: tests of the changing-state hypothesis. Journal of Experimental Psychology: Learning, Memory, and Cognition, 23, 459-471. doi: 10.1037/0278-7393.23.2.459 المالسلسل

Beatty, E. L., Jobidon, M. E., Bouak, F., Nakashima, A., Smith, I., Lam, Q., ... Vartanian, O. (2015). Transfer of training from one working memory task to another: behavioural and neural evidence. Frontiers in Systems Neuroscience, 9. doi:10.3389/ fnsys.2015.00086 إلس

Bergmann, H. C., Rijpkema, M., Fernández, G., \& Kessels, R. P. C. (2012). The effects of valence and arousal on associative working memory and long-term memory. PLoS One, 7. doi: 10.1371/ journal.pone.0052616 المالسلس

Blacker, K. J., Negoita, S., Ewen, J. B., \& Courtney, S. M. (2017). $\mathrm{N}$-back versus complex span working memory training. Journal of Cognitive Enhancement, 1, 434-454. doi: 10.1007/ s41465-017-0044-1 سلس

Broadbent, D. E. (1978). The current state of noise research: Reply to Poulton. Psychological Bulletin, 85, 1052-1067. doi:

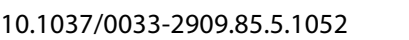

Byrne, E. M., Gilbert, R. A., Kievit, R., \& Holmes, J., PhD. (2019, April 16). Evidence for separate backward recall and n-back working memory factors: A large-scale latent variable analysis. Retrieved from https://psyarxiv.com/bkja7/

Chepenik, L. G., Cornew, L. A, \& Farah, M. J. (2007). The influence of sad mood on cognition. Emotion, 7, 802-811.doi:

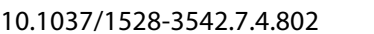

Choi, M.-H., Min, Y.-K., Kim, H.-S., Kim, J.-H., Yeon, H.-W., Choi, J.-S., Chung, S.-C. (2013). Effects of three levels of arousal on 3-back working memory task performance. Cognitive Neuroscience, 4, 1-6. doi: 10.1080/17588928.2011.634064 الميلس

Coan, J. A., \& Allen, J. J. B (2003). Frontal EEG asymmetry and the behavioral activation and inhibition systems. Psychophysiology, 40, 106-114. doi: 10.1111/1469-8986.00011 المالسليلاس

Cowan, N. (1999). An embedded-process model of working memory. In A. Miyake \& P. Shah (Eds.), Models of working memory: Mechanisms of active maintenance and executive control (pp. 62-101). Cambridge, UK: Camdridge Unviersity Press

Curci, A., Soleti, E., Lanciano, T., Doria, V., \& Rimé, B. (2015). 
Balancing emotional processing with ongoing cognitive activity: The effects of task modality on intrusions and rumination. Frontiers in Psychology, 6. doi: 10.3389/fpsyg.2015.01275 سلسلسل|

D'Esposito, M., Aguirre, G. K., Zarahn, E., Ballard, D., Shin, R. K., \& Lease, J. (1998). Functional MRI studies of spatial and nonspatial working memory. Cognitive Brain Research, 7, 1-13. doi:

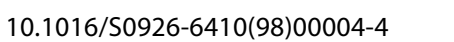

D'Esposito, M. (2007). From cognitive to neural models of working memory. Philosophical Transactions of the Royal Society $B$, 362, 761-772. doi: 10.1098/rstb.2007.2086 سلسلس

D'Esposito, M., \& Postle, B. R. (2015). The cognitive neuroscience of working memory. Annual Review of Psychology, 66, 115-142. doi: 10.1146/annurev-psych-010814-015031 الس الس

Dalgleish, T., \& Yiend, J. (2006). The effects of suppressing a negative autobiographical memory on concurrent intrusions and subsequent autobiographical recall in dysphoria. Journal of Abnormal Psychology, 115, 467-473. doi: 10.1037/0021843X.115.3.467 سلس

Dolan, R. J. (2002, November). Emotion, cognition, and behavior. Science, 298, 1191-1194. doi: 10.1126/science.1076358 الس السلس

Dolcos, F., \& Denkova, E. (2014). Current emotion research in cognitive neuroscience: linking enhancing and impairing effects of emotion on cognition. Emotion Review, 6, 362-375. doi: 10.1177/1754073914536449 (1)

Elliott, E. M., \& Cowan, N. (2005). Coherence of the irrelevantsound effect: Individual profiles of short-term memory and susceptibility to task-irrelevant materials. Memory \& Cognition, 33, 664-675. Retrieved from http://www.ncbi.nlm.nih.gov/ pubmed/16248331 الم السلسلس

Engle, R. W., \& Oransky, N. (1999). The evolution from short-term to working memory: Multi-store to dynamic models of temporary storage. In R. Sternberg (Ed.), The nature of human cognition (pp. 514-555). Cambridge, MA: MIT Press.

Esmaeili, M. T., Karimi, M., Tabatabaie, K. R., Moradi, A., \& Farahini, N. (2011). The effect of positive arousal on working memory. Procedia - Social and Behavioral Sciences, 30, 1457-1460. doi:

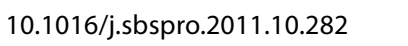

Fairfield, B., Mammarella, N., Di Domenico, A., \& Palumbo, R. (2014). Running with emotion: When affective content hampers working memory performance. International Journal of Psychology, 50, 161-164. doi: 10.1002/ijop.12101 الس السلسل

Fredrickson, B. L. (2001). The role of positive emotions in positive psychology: The broaden-and-build theory of positive emotions. American Psychologist, 56, 218-226. doi:10.1037//0003066X.56.3.218 الس سلس

Gable, P. A., \& Harmon-Jones, E. (2008). Approach-motivated positive affect reduces breadth of attention. Psychological Science,

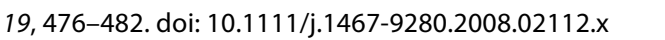

Garcia, A., Uribe, C. E., Tavares, M. C. H., \& Tomaz, C. (2011). EEG and autonomic responses during performance of matching and non-matching to sample working memory tasks with emotional content. Frontiers in Behavioral Neuroscience, 5, 1-9.

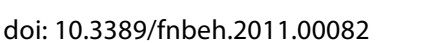

Gotoh, F. (2012). Affective valence of words impacts recall from auditory working memory. Journal of Cognitive Psychology, 24, 117-124. doi: 10.1080/20445911.2011.589380 الس الس الس

Grimm, S., Weigand, A., Kazzer, P., Jacobs, A. M., \& Bajbouj, M. (2012). Neural mechanisms underlying the integration of emotion and working memory. Neurolmage, 61, 1188-1194. doi: 10.1016/j.neuroimage.2012.04.004 الس السلس

Grissmann, S., Faller, J., Scharinger, C., Spüler, M., \& Gerjets, P. (2017). Electroencephalography based analysis of working memory load and affective valence in an n-back task with emotional stimuli. Frontiers in Human Neuroscience, 11. doi: 10.3389/fnhum.2017.00616 سلس

Higgins, J. P. T., \& Green, S. (2011). Cochrane handbook for systematic reviews of interventions version 5.1.0. Retrieved from: www. handbook.cochrane.org

Ivanova, M. V., Kuptsova, S. V., \& Dronkers, N.F. (2017). A comparison of two working memory tasks in aphasia. Aphasiology, 31, 265-281. doi: 10.1080/02687038.2016.1172699 السلسلس

Jaeggi, S. M., Buschkuehl, M., Perrig, W. J., \& Meier, B. (2010). The concurrent validity of the $\mathrm{N}$-back task as a working memory measure. Memory, 18, 394-412. doi: 10.1080/09658211003702171 السلسلس

Jin, Y., Li, X., \& Luo, Y. (2013). Effects of emotional content on working memory: Behavioral and electrophysiological evidence. In D. Liu, C. Alippi, D. Zhao, \& A. Hussain (Eds.), Advances in brain inspired cognitive systems, (pp. 136-144). Berlin, Germany: Springer-Verlag.

Jones, D. M., Miles, C., \& Page, J. (1990). Disruption of proofreading by irrelevant speech: Effects of attention, arousal or memory? Applied Cognitive Psychology, 4, 89-108. doi: 10.1002/ acp.2350040203 السلسلس

Jonides, J., \& Smith, E. E. (1997). The architecture of working memory. In M. D. Rugg (Ed.), Cognitive neuroscience (pp. 243276). Hove, England: Psychology Press.

Kane, M. J., Conway, A. R. A., Miura, T. K., \& Colflesh, G. J. H. (2007). Working memory, attention control, and the n-back task: A question of construct validity. Journal of Experimental Psychology: Learning, Memory, and Cognition, 33, 615-622. doi: 10.1037/0278-7393.33.3.615 المالسلسلس

Kensinger, E. A., \& Corkin, S. (2003). Effect of negative emotional content on working memory and long-term memory. Emotion, 3, 378-393. doi: 10.1037/1528-3542.3.4.378 السلسلسل

Klingner, J., Tversky, B., \& Hanrahan, P. (2011). Effects of visual and verbal presentation on cognitive load in vigilance, memory, and arithmetic tasks. Psychophysiology, 48, 323-332. doi: 10.1111/j.1469-8986.2010.01069.x سلس الس الس

Kreibig, S. D., Wilhelm, F. H., Roth, W. T., Gross, J. J. (2007). Cardiovascular, electrodermal, and respiratory response patterns to fear and sadness-inducing films. Psychophysiology, 44, 787-806. doi: 10.1111/j.1469-8986.2007.00550.x 每

Kopf, J., Dresler, T., Reicherts, P., Herrmann, M. J., \& Reif, A. (2013). 
The effect of emotional content on brain activation and the late positive potential in a word n-back task. PLoS One, 8, 1-11. doi: 10.1371/journal.pone.0075598 الس السلسلاس

Ledoux, J. E. (1989). Cognitive-emotional interactions in the brain. Cognition \& Emotion, 3, 267-289. doi: 10.1080/02699938908412709

Levens, S. M., \& Phelps, E. A. (2008). Emotion processing effects on interference resolution in working memory. Emotion, 8 , 267-280. doi: 10.1037/1528-3542.8.2.267 الس السلسل

Levens, S. M., \& Phelps, E. A. (2010). Insula and orbital frontal cortex activity underlying emotion interference resolution in working memory. Journal of Cognitive Neuroscience, 22, 2790-2803. doi: 10.1162/jocn.2010.21428 سلس الس

Li, X., Chan, R. C., \& Luo, Y. (2010). Stage effects of negative emotion on spatial and verbal working memory. BMC Neuroscience,

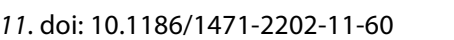

Lindström, B. B. R., \& Bohlin, G. (2011). Emotion processing facilitates working memory performance. Cognition \& Emotion, 25, 37-41. doi: 10.1080/02699931.2010.527703 الس الس

Ma, W. J., Husain, M., \& Bays, P. M. (2014). Changing concepts of working memory. Nature Neuroscience, 17, 347-356. doi:10.1038/nn.3655 Шلسلس

Martin, E., \& Kerns, J. G. (2011). The influence of positive mood on different aspects of cognitive control. Cognition and Emotion, 25, 265-279. doi: 10.1080/02699931.2010.491652 سلسلس

Mather, M., Mitchell, K. J., Raye, C. L., Novak, D. L., Greene, E. J., \& Johnson, M. K. (2006). Emotional arousal can impair feature binding in working memory. Journal of Cognitive Neuroscience, 18, 614-625. doi: 10.1162/jocn.2006.18.4.614 الس السلسل

Mayshak, R., Sharman, S. J., \& Zinkiewicz, L. (2016). The impact of negative online social network content on expressed sentiment, executive function, and working memory. Computers in Human Behavior, 65, 402-408. doi: 10.1016/j.chb.2016.09.002 Wلس لسلس

Meiran, N., Chorev, Z., \& Sapir, A. (2000). Component processes in task switching. Cognitive Psychology, 41, 211-253. doi: 10.1006/cogp.2000.0736 سلس

Miyake, A., \& Friedman, N. P. (2012). The nature and organization of individual differences in executive functions: Four general conclusions. Current Directions in Psychological Science, 21, 8-14. doi:10.1177/0963721411429458 1لس

Miyake, A., Friedman, N. P., Emerson, M. J., Witzki, A. H., Howerter, A., \& Wager, T. D. (2000). The unity and diversity of executive functions and their contributions to complex "Frontal Lobe" tasks: A latent variable analysis. Cognitive Psychology, 41,

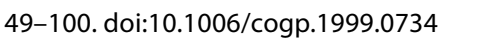

Moher, D., Liberati, A., Tetzlaff, J., \& Altman, D. G. (2009). Preferred reporting items for systematic reviews and metaanalyses: The PRISMA statement. Annals of Internal Medicine, 151, 264-269. Retrieved from http://annals.org/ on 08/07/2018

Moran, T. P. (2016). Anxiety and working memory capacity: A meta-analysis and narrative review. Psychological Bulletin, 142,

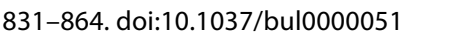

Morrison, R. G. (2005). Thinking in working memory. In K. J. Holyoak \& R. G. Morrison (Eds.), Cambridge handbook of thinking and reasoning (pp. 457-473). Cambridge, MA: Cambridge University Press.

Nguyen, T., \& Grahn, G. A. (2017). Mind your music: the effects of music-induced mood and arousal across different memory tasks. Psychomusicology: Music, Mind, and Brain, 27, 81-94. doi: 10.1037/pmu0000178 البلسلس

Osaka, M., Yaoi, K., Minamoto, T., \& Osaka, N. (2013). When do negative and positive emotions modulate working memory

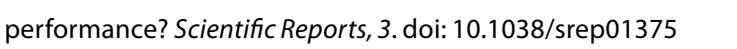

Ochsner, K. N. (2000). Are affective events richly recollected or simply familiar? The experience and process of recognizing feelings past. Journal of Experimental Psychology: General, 129,

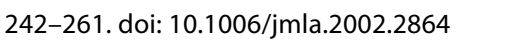

Paivio, A. (1991). Dual coding theory: Retrospect and current status. Canadian Journal of Psychology, 45, 255-287. doi: 10.1037/ h0084295 (ل)

Palmiero, M., Nori, R., Rogolino, C., D'Amico, S., \& Piccardi, L. (2015). Situated navigational working memory: The role of positive mood. Cognitive Processing, 16, 327-330. doi: 10.1007/ s10339-015-0670-4 سلس

Palmiero, M., Nori, R., Rogolino, C., D’Amico, S., \& Piccardi, L. (2016). Sex differences in visuospatial and navigational working memory: The role of mood induced by background music. Experimental Brain Research, 234, 2381-2389. doi: 10.1007/ 500221-016-4643-3 سلس سل

Palmiero, M., \& Piccardi, L. (2017). The role of emotional landmarks on topographical memory. Frontiers in Psychology, 8. doi: 10.3389/fpsyg.2017.00763 الس الس الس

Pessoa, L. (2013). The cognitive-emotional brain: From interactions to integration. Maryland: MIT Press.

Pratto, F., \& John, O. (1991). Automatic vigilance: The attentiongrabbing power of negative social information. Journal of Personality and Social Psychology, 61, 380-391.

Redick, T. S., \& Lindsey, D. R. B. (2013). Complex span and n-back measures of working memory: A meta-analysis. Psychonomic Bulletin \& Review, 20, 1102-1113. doi: 10.3758/s13423-013-0453-9 السلسلسلس

Ribeiro, F. S., Albuquerque, P. B., \& Santos, F. H. (2018). Relations between emotion and working memory: Evidence from behavioural and psychophysiological studies. Psicologia em Estudo, 23. doi: 10.4025/psicolestud.v23i0.35734 سلس

Rock, P. L., Roiser, J. P., Riedel, W. J., \& Blackwell, A. D. (2014). Cognitive impairment in depression: A systematic review and meta-analysis. Psychological Medicine, 44, 2029-2040. doi:

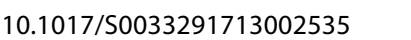

Salamé, P., \& Baddeley, A. (1989). Effects of background music on phonological short-term memory effects of background music. The Quarterly Journal of Experimental Psychology Section A, 41, 107-122. doi: 10.1080/14640748908402355 الس الس الس

Santos, F. H., Soares, R. F. G., \& Albuquerque, P. B. (2015, September). How emotions modulate working memory capac- 
ity? Poster presented at the 19th Conference of the European Society for Cognitive Psychology (ESCOP), Cyprus, Greece.

Seibert, P. S., \& Ellis, H. C. (1991). Irrelevant thoughts, emotional mood states, and cognitive task performance. Memory \& Cognition, 19, 507-513. doi: 10.3758/BF03199574 سلس

Smith, E. E., \& Jonides, J. (1999, March). Storage and executive processes in the frontal lobes. Science, 283, 1657-1661. doi: 10.1126/science.283.5408.1657 المالسلس

Soares, R. F. G. (2015). Influência da indução de emoções positivas e negativas na memória operatória [The influence of positive and negative emotional induction in working memory] (Master's thesis). Retrieved from http://hdl.handle. net/1822/37602

Spachtholz, P., Kuhbandner, C., \& Pekrun, R. (2014). Negative affect improves the quality of memories: Trading capacity for precision in sensory and working memory. Journal of Experimental Psychology.

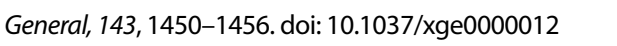

Spies, K., Heese, F. W., \& Hunimitzsch, C. (1996). Mood and capacity in Baddeley's model of human memory. Zeitschrift Fur Psychologie, 204, 367-381. الملسلسلس

Storbeck, J., \& Maswood, R. (2015). Happiness increases verbal and spatial working memory capacity where sadness does not: Emotion, working memory and executive control. Cognition \& Emotion, 30, 1-14. doi: 10.1080/02699931.2015.1034091 الس الس الس
Schweizer, S., \& Dalgleish, T. (2016). The impact of affective contexts on working memory capacity in healthy populations and in individuals with PTSD. Emotion, 16, 16-23. doi:10.1037/ emo0000072 سلس

Taruffi, L., Pehrs, C., Skouras, S., \& Koelsch, S. (2017). Effects of sad and happy music on mind-wandering and the default mode network.

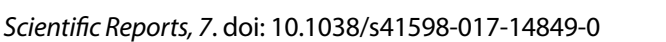

Tyng, C. M., Amin, H. U., Saad, M. N. M., \& Malik, A. S. (2017). The influences of emotion on learning and memory. Frontiers in Psychology, 8. doi: 10.3389/fpsyg.2017.01454 (لسلسل

Vuilleumier, P., \& Huang, Y.-M. (2009). Emotional attention: Uncovering the mechanisms of affective biases in perception. Current Directions in Psychological Science, 18, 148-152. doi:10.1111/j.1467-8721.2009.01626.x السلسلس

Xie, W., \& Zhang, W. (2016). Negative emotion boosts quality of visual working memory representation. Emotion, 16, 760-774.

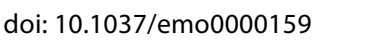

Yang, H., Yang, S., \& Isen, A. M. (2013). Positive affect improves working memory: Implications for controlled cognitive processing. Cognition \& Emotion, 27, 474-482. doi:10.1080/02699 931.2012 .713325 1لس

RECEIVED 09.05.2018 | ACCEPTED 24.05.2019 